\title{
Disseminated Abdominal Actinomycosis: An Unusual Cause of Obstruction
}

\author{
${ }^{1}$ Cristina M Álvarez, ${ }^{2}$ José 0 Martínez, ${ }^{3}$ Mónica G Noriega, ${ }^{4}$ Enrique T Martínez, ${ }^{5}$ Federico \\ C Suescun, ${ }^{6}$ Roberto F Santiago, ${ }^{7}$ Juan C R Sanjuan, ${ }^{8}$ Patrizio Petrone
}

\begin{abstract}
Introduction: Actinomycosis is an uncommon diagnosis, involving the abdominal cavity in around $20 \%$ of cases. It is characterized by its tendency to form masses and abscesses that, added to its subacute onset, can be difficult to differentiate from other conditions. Obstruction is rare but is mainly associated with the presence of an abnormal growth of tissue as mimicking a malignancy. Pelvic forms are usually related to prolonged use of intrauterine devices, although other causes within mucosal disruption have been described.
\end{abstract}

Case report: A 36-year-old woman with type 1 diabetes mellitus and diabetic nephropathy who underwent pancreas-kidney transplantation, with no incidences during the surgical procedure. She developed fever, which did not disappear despite drainage of abdominal fluid collections. Subsequently, she developed abdominal obstructive symptoms requiring urgent surgery. During the exploratory laparotomy, numerous small white formations were identified scattered throughout the entire abdominal cavity, causing firm adhesions between bowels. During the procedure, biopsies were taken and adhesiolysis was performed.

Conclusion: Abdominal actinomycosis must be considered not just in the presence of fever and weight loss but also must be rule out in unusual onsets such as small bowel obstruction. To our knowledge this presentation as disseminated lesions has not been described in the literature.

Keywords: Abdominal presentation, Actinomycosis, Bowel obstruction.

\section{RESUMEN}

Antecedentes: La actinomicosis constituye un diagnóstico poco frecuente, afectando la región abdominal en alrededor del $20 \%$ de los casos. Se caracteriza por su tendencia a formar masas y abscesos que, junto con un inicio subagudo, pueden imitar diversas afecciones. La obstrucción intestinal es rara, asociándose principalmente con la presencia de un

\footnotetext{
${ }^{1-8} \mathrm{MD}$

${ }^{1,3-7}$ Cirugía General y del Aparato Digestivo, Hospital Universitario Marqués de Valdecilla, Santander, Spain

${ }^{2}$ Servicio de Aparato Digestivo y Endoscopias, Hospital Universitario Marqués de Valdecilla, Santander, Spain

${ }^{8}$ Department of Surgery - NYU Winthrop Hospital, Mineola, Long Island, New York, USA

Corresponding Author: Patrizio Petrone, MD MPH MHSA FACS, Department of Surgery - NYU Winthrop Hospital, Mineola, Long Island, New York, USA, Email: patrizio.petrone@gmail. com, patrizio.petrone@nyulangone.org
}

crecimiento anómalo de tejido lo cual puede simular malignidad. Las formas pélvicas generalmente están relacionadas con el uso prolongado de dispositivos intrauterinos $u$ otras causas relacionadas con una alteración de la mucosa subyacente.

Caso: Mujer de 36 años con diabetes mellitus tipo 1 y nefropatía diabética que se sometió a trasplante de páncreas y riñón, sin incidencias durante el procedimiento quirúrgico. Comenzó con fiebre, que no desapareció a pesar del drenaje de colecciones intraabdominales. Posteriormente desarrolló síntomas de obstrucción intestinal que requirieron cirugía urgente para su resolución. Durante la laparotomía se observaron pequeñas lesiones blanquecinas diseminadas por la cavidad abdominal, que causaban adherencias firmes entre asas intestinales. Tras tomar muestras para biopsia se realizó adhesiolisis.

Conclusión: El diagnóstico de actinomicosis abdominal debe descartarse en casos inusuales que se presenten con fiebre, pérdida de peso y obstrucción del intestino delgado en pacientes como el descrito en este caso clínico. A nuestro entender, esta presentación como lesiones diseminadas no se ha descrito en la literatura.

Palabras clave: Actinomicosis, Localización abdominal, Obstrucción intestinal.

\section{RESUMO}

Antecedentes: A actinomicose é um diagnóstico raro, que afeta a região abdominal em cerca de $20 \%$ dos casos. Caracteriza-se pela sua tendência a formar massas e abscesos que, juntamente com um início subagudo, podem imitar diversas condições. A obstrução intestinal é rara, principalmente associada à presença de crescimento anormal do tecido que pode imitar a malignidade. As formas pélvicas são geralmente relacionadas ao uso prolongado de dispositivos intra-uterinos ou a outras causas relacionadas a uma alteração da mucosa subjacente.

Caso: Uma mulher de 36 anos com diabetes mellitus tipo 1 e nefropatia diabética submetidos a transplante de pâncreas e rim, sem incidentes durante o procedimento cirúrgico. Começou com febre, que não desapareceu apesar da drenagem das coleções intra-abdominais. Mais tarde, ele desenvolveu sintomas de obstrução intestinal que exigiam cirurgia urgente para resolução. Durante a laparotomia, observaram-se pequenas lesões esbranquiçadas disseminadas através da cavidade abdominal, o que causou adesões firmes entre os laços intestinais. After taking samples for biopsy, adhesiolysis was performed.

Conclusão: O diagnóstico de actinomicose abdominal deve ser descartado em casos incomuns que apresentam febre, perda de peso e obstrução do intestino delgado em pacientes como o descrito neste caso clínico. Após uma busca exaustiva, não foram encontradas publicações na literatura descrevendo esta apresentação clínica no contexto de lesões disseminadas. 
Palavras clave: Actinomicose; Localização abdominal; Obstrução intestinal.

How to cite this article: Alvarez CM, Martínez JO, Noriega MG, Martínez ET, Suescun FC, Santiago RF, Sanjuan JCR, Petrone P. Disseminated Abdominal Actinomycosis: An Unusual Cause of Obstruction. Panam J Trauma Crit Care Emerg Surg 2018;7(2):164-166.

Source of support: Nil

\section{Conflict of interest: None}

\section{INTRODUCTION}

Actinomycosis is a rare entity caused by microorganisms of the genus Actinomyces, a gram-positive anaerobic germ, and saprophyte in oropharynx, gastrointestinal and genitourinary tracts. ${ }^{1-7}$ Estimation of the incidence is difficult because of unrecognized cases that are successfully treated empirically. At the same time, its frequency has diminished with the use of antibiotics and improved dental hygiene. ${ }^{1,3,4}$

Abdominal actinomycosis accounts for $20 \%$ of the cases, involving the appendix and caecum in $66 \%{ }^{1}$ of the presentations, only overcome by the cervicofacial form in $50 \%$ to $65 \%$. ${ }^{2,5}$ Opportunistic infections are the result from a loss of mucosal integrity as this microorganism is unable to cross the normal mucosa barrier. ${ }^{6,8}$ Therefore, are commonly related to surgery, trauma, appendicitis or diverticulitis. ${ }^{1-3,5}$ Once it has penetrated the mucosa, the spread by continuity is more common than the lymphatic and hematogenous forms. ${ }^{2}$

Clinical presentation may mimic different diseases, with an insidious course and no specific symptoms. ${ }^{5,6}$ The onset is usually chronic and includes pain, fever, weight loss, and anorexia. It is characterized by its capacity to invade surrounding tissues and to form masses simulating a malignancy. ${ }^{1-6,8}$

Based on these reasons, diagnosis may be challenging before, or even during surgery, and can lead to an increased morbidity and mortality., ${ }^{3,6}$ Findings are usually mistaken for acute inflammatory pathologies or tumors, and radiology may not be helpful neither. ${ }^{6-8}$ Abdominal $\mathrm{CT}^{\prime}$ 's main sign is bowel wall thickening commonly mislead as Crohn's disease, while infiltrative mass, solid or cystic formations may also be found. ${ }^{1,5}$

\section{CASE REPORT}

A 36-year-old woman underwent combined pancreaskidney transplantation. She has been diagnosed of Type 1 diabetes mellitus (DM) 24 years ago. Subsequently, she had developed a diabetic nephropathy and chronic kidney disease. She also has hypertension and dyslipidemia, and a bilateral salpingectomy was performed one year prior due to salpingitis and septic shock.

No incidences were reported during the surgical procedure. Seven days after the surgery she developed fever. An abdominal CT was performed showing an intraabdominal collection that was resolved with percutaneous drainage and antibiotics adjusted to antibiogram. However, after a first initial improvement, she began with symptoms of intestinal obstruction that were not resolved with conservative management. An abdominal CT scan was repeated and the imaging was compatible with postoperative adhesions, and urgent exploratory laparotomy was performed.

Multiple nodular lesions closely adhered to the peritoneum, scattered throughout the abdominal cavity were observed at laparotomy, causing adhesions between bowels (Figs 1 and 2) firmly. During the procedure, biopsies were taken and adhesiolysis was performed. Histology report was written as "sulfur granules", and Actinomyces viscosus was grown from. Surgery led to a rapid improvement of the transit, with a rapid transition to oral diet. The patient evolved favorably after prolonged with intravenous penicillin treatment and was discharged from hospital uneventfully.

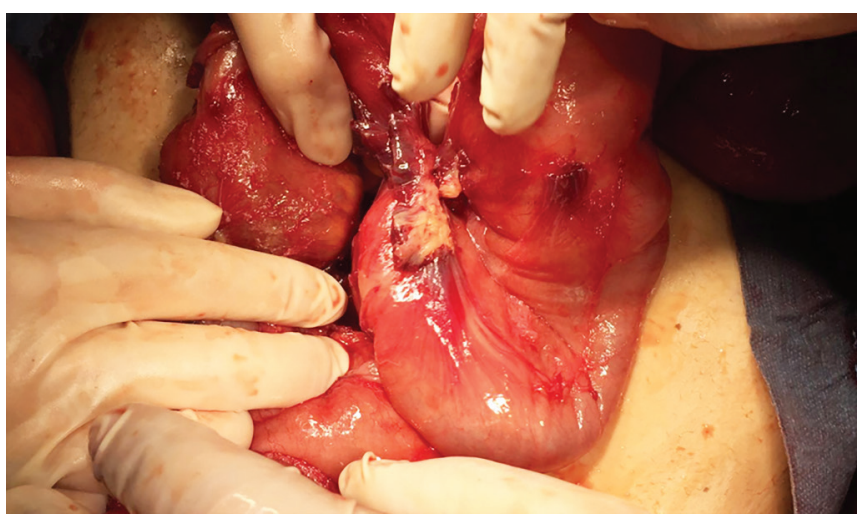

Fig. 1: White small mass as a strong adhesion between bowels.

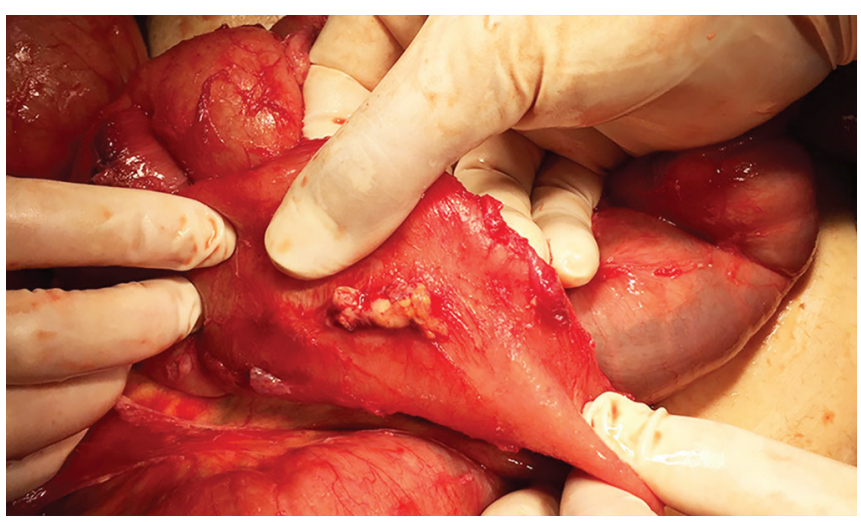

Fig. 2: Small mass of approximately $2 \mathrm{~cm}$, firmly adhered to the parietal peritoneum. 


\section{DISCUSSION}

Actinomyces israelii is the major human pathogen, 5,7,8 but at least five other Actinomyces species, included Actinomyces viscosus may also be responsible for similar or identical clinical symptomatology. ${ }^{1,3}$

Pelvic actinomycosis has recently become more prevalent. It is associated with the prolonged use of intrauterine devices (IUD), most likely spread through fallopian tubes leading to pelvic abscesses formation. ${ }^{2,6}$

Have been reported local and general risk factors predisposing this infection to occur. In a recent observational study, Bonnefond et al. ${ }^{3}$ have reported local risk factors in more than $70 \%$ of cases, including dental procedure or poor dentition, radiotherapy, IUD, surgery or trauma. General risk factors include malignancy (22\%), DM and treatment with immunosuppressors (14\% each), and as well as previous chemotherapy, radiotherapy, and alcoholism.

The diagnosis of actinomycosis depends on gram stain which reveals gram-positive branching filaments. ${ }^{6}$ Definitive diagnosis requires either visualization of the pathogen, the presence of "sulfur granules", or culture of Actinomyces. ${ }^{7,8}$

Antibiotics as the only treatment are indicated when uncomplicated abdominal actinomycosis is diagnosed. Although there are no consensus about the dosage and duration of antibiotic treatment, intravenous penicillin G for 4-6 weeks, followed by oral penicillin $\mathrm{V}$ for 2-12 months is recommended. ${ }^{1}$ Prolonged antibiotic treatment is required due to poor penetration into the fibrotic tissues. ${ }^{2,6}$

Surgery is reserved for patients who do not respond to initial therapy or in severe spread cases (fistulas, necrosis or abscesses). 1,6 Prolonged antibiotic therapy should be administered in combination with surgery to achieve a lasting resolution of the infection and allowed a shorten length of treatment has been suggested. ${ }^{7,8}$ Heidt et al. ${ }^{9}$ stated that surgery may be only indicated in specific complications such as mechanical ileus. The combination of antibiotic therapy and surgery can lead to good outcomes in more than $90 \%$ of cases. ${ }^{1}$

\section{CONCLUSION}

The case reported herein is unique in its clinical presentation. Actinomycosis is a disease that must be considered by the surgeon when faced with a clinical picture of subacute onset or chronic inflammatory lesions. Although fever or abdominal mass in immunocompromised patients with the previous history of surgery is the most common clinical form, actinomycosis must be ruled out in clinical presentations where the small bowel obstruction is the main clinical symptom.

\section{REFERENCES}

1. Gómez-Torres GA, Ortega-Gárcia OS, Gutierrez-López EG, Carballido-Murguía CA, et al. A rare case of subacute appendicitis, actinomycosis as the final pathology reports: A case report and literature review. Int J Surg Case Rep 2017;36:46-49.

2. Choi M, Jeong HB, Jung NL, Sanghui P, Lee W. Clinical features of abdominopelvic actinomycosis: Report of twenty cases and literature review. Yonsei Med J 2009;50(4):555-559.

3. Bonnefond S, Catroux M, Melenotte C, Karkowski L, et al. Clinical features of actinomycosis A retrospective, multicenter study of 28 cases of miscellaneous presentations. Medicine (Baltimore) 2016;95(24)e3923.

4. Acevedo F, Baudrand R, Letelier LM, Gaete P. Actinomycosis: a great pretender. Case reports of unusual presentations and a review of the literature. Int J Infect Dis 2008;12(4): 358-362.

5. Pusiol T, Morichetti D, Pedrazzani C, Ricci F. Abdominalpelvic actinomycosis mimicking malignant neoplasm. Infect Dis Obstet Gynecol 2011;2011:747059. Published online 2011 Aug 29.

6. Hildyard CAT, Gallacher NJ, Macklin PS. Abdominopelvic actinomycosis mimicking disseminated peritoneal carcinomatosis. BMJ Case Rep 2013. (nov21_1) pii: bcr2013201128

7. Karagulle E, Turan H, Turk E, Kiyici H, Yildirim E, Moray G. Abdominal actinomycosis mimicking acute appendicitis. Can J Surg 2008;51(5):E109-E110.

8. Sung HY, Lee IS, Kim SI, Jung SE, Kim SW, Kim SY, et al. Clinical features of abdominal actinomycosis: A 15-year experience of a single institute. J Korean Med Sci 2011;26(7):932-937.

9. Heidt J, Jansen CL, Leyten EMS. An abdominal mass: Not a 'clear cut' case! Neth J Med 2010;68(10):319-321. 